\title{
Галина Зеленина. Огненный враг марранов. Жизнь и смерть под надзором ИНКВИЗИЦИИ.
}

\author{
М.; СПб.: Центр гуманитарных инициатив, 2017. \\ ISBN: 978-5-98712-824-4. 396 c.
}

DOI: $10.31168 / 2658-3364.2020 .2 .23$

В книге Галины Зелениной исследуются различные аспекты взаимоотношений испанских марранов (крестившихся евреев) и католической церкви, представленной в книге как рядовыми верующими («старыми христианами»), так и властями, в первую очередь Супремой - испанской инквизицией. Основным источником исследования послужили материалы инквизиционных процессов в городе Сьюдад-Реал, расположенном в Кастилии, в 70 км от Толедо, на пути в Кордову. Эти материалы включают два разных типа документов: показания свидетелей обвинения и показания, представленные защитой с целью доказать ненадежность этих свидетелей. Документы относятся к периоду с 1483 по 1527 гг, однако хронологические рамки исследования, в котором заявленные темы рассматриваются, в том числе и в диахроническом разрезе, существенно шире: автор привлекает и свидетельства из текстов XIII-XIV вв., и источники второй половины XVI-XVII вв.

Книга включает введение и три раздела, названия которых отражают их содержание: «Марраны между иудаизмом и христианством», «Марраны между собой», «Марраны и инквизиция». Как и во всех исследованиях, опирающихся на документы инквизиции, первый и ключевой вопрос, возникающий у самого исследователя и у читателей: насколько можно доверять этому источнику? Обсуждая во введении историографию проблемы, Галина Зеленина затрагивает, в частности, полемику разных исторических школ по данному вопросу, но ее собственный подход, декларируемый в книге, избавляет ее от необходимости пытаться решить неразрешимую задачу верификации неверифицируемого. В раз- 
ных местах книги она неоднократно пишет о том, что мы не знаем и никогда не узнаем, были ли обвиненные действительно «виновны» в приписываемых им действиях, а оправданные - невиновны, имели ли место упомянутые свидетелями факты или показания с разной степенью умелости были сфабрикованы.

Исследовательница принципиально также отказывается от любых оценочных дихотомий «жертвы - преследователи», «герои - гонители», «еретики - защитники веры», под знаком которых долгое время развивалась историография по данной теме.

Еще одна проблема, весьма популярная в современной иудаике это вопрос о соотношении в средневековом восприятии евреев религиозно-конфессионального и этнического аспектов (другими словами, имеем ли мы дело в этот период с антисемитизмом или анти-иудаизмом) и трансформации этого восприятия в раннее Новое время. Зеленина, упомянув во введении эту тему, намеренно оставляет ее за рамками рассмотрения. В определенном смысле однозначный ответ на поставленный таким образом вопрос порождает очередную дихотомию из числа тех, которые исследовательница стремится избегать.

Зеленина определяет свой подход как основанный на методологии исторической антропологии, гендерной истории, истории идей. Ее интересуют не столько сами факты, сколько бытовавшие в том или ином сообществе (или в обществе в целом) идеи, представления и парадигмы, под влиянием которых свидетели, обвинители и защита формулировали свои мысли (не очень важно, соответствовали или не соответствовали они реальности) в тех или иных образах, апеллировали, к тем или иным идеалам и моделям.

В первом разделе в центре внимания автора находятся религиозные практики и обычаи марранов, их эволюция во времени. Она также демонстрирует, каким образом некоторые обряды и практики (например, приготовление определенных блюд) приобретали, с точки зрения общества и инквизиторов, «иудейские» коннотации и служили поводом для подозрений и обвинений. Одна из глав этого раздела посвящена очень интересной, на мой взгляд, теме - изменению отношения марранской общины к Торе и постепенному превращению ее в «воображаемую книгу», остававшуюся в центре исторической памяти, но не существующую в материальной реальности.

Второй раздел включает сюжеты, связанные с взаимоотношениями внутри марранских общин. Опираясь на показания свидетелей и главным образом на заявления по отводу свидетелей, Галина Зеленина реконструирует механизмы и анатомию внутренних конфликтов между самими марранами, а также конфликтов между марранами и их соседями - «старыми христианами». Эта часть исследования демонстрирует, каким образом в процессе дознаний по делам о «тайном иудействе» про- 
исходил «перевод» свидетельских показаний и инквизиторских вердиктов с языка социального на религиозно-правовой язык и обратно. Инквизиция видела (или хотела видеть) религиозные мотивы в ситуациях и конфликтах, за которыми стояли, скорее всего, соседские ссоры, зависть, соперничество за место в социальной иерархии и т.п. В этом плане весьма важным представляется обобщающий вывод Галины Зелениной о том, что ключевым понятием при описании действий «противной стороны» (будь то гипотетически «иудействующие» марраны, недостойные свидетели или сама инквизиция) оказывается не «преступление» или «грех», а «бесчестье». Под этим термином может скрываться как арест или даже аутодафе, так и указание со стороны марранов на чисто прагматические цели инквизиторов, желающих исключительно отнять у обвиняемых их собственность.

В пяти главах третьего раздела рассмотрены различные сюжеты, связанные с взаимодействием марранов и сефардов с инквизицией. Отказавшись, как уже говорилось выше, от традиционных «черно-белых» интерпретаций этого противостояния, Галина Зеленина анализирует его с точки зрения средств и методов, использовавшихся в "идейном» соперничестве сторон для утверждения собственного морального превосходства. Представляются интересными наблюдения исследовательницы по поводу своего рода «зеркальности» в использовании конверсо (марранами) и инквизиторами библейских аллюзий, концепции святости и даже мессианской идеи. Описанная Галиной Зелениной эволюция отношения конверсо к почитанию святых - от полного отрицания посредством насмешек и надругательств через конкуренцию исторических (библейских) нарративов о мученичестве и мести до формирования собственных культов (марранов, погибших от рук инквизиции, с одной стороны, и испанских инквизиторов, погибших «на боевом посту» - с другой) - находит любопытные параллели в эволюции отношения протестантов к святости (о чем автор вскользь упоминает), а также в более ранней истории формирования катарского «пантеона».

Не менее интересные параллели обнаруживаются и во втором сюжете: об использовании в полемике еврейских и христианских авторов XVI-XVII вв. образов «эсхатологического зверя» из Пророчества Даниила и Откровения Иоанна Богослова. Если христианское описание «моисеевой ереси» в таком ключе вполне традиционно, то в применении подобной образности конверсо в XVII в. можно усмотреть параллель (если не влияние) протестантской историографии того времени, пестревшей подобными аллюзиями.

Отдельный сюжет в книге, проходящий практически через все ее главы, составляет гендерная тема. Рассматривая различные аспекты существования марранской общины (от обычаев, связанных с рождением ребенка, до отношения к культу Девы Марии) в диахронической перспек- 
тиве исследовательница выявляет интересную общую закономерность чередования, если можно так сказать, гендерных оснований марранской культуры. В процессе постепенной утраты марранами связей со своими прежними единоверцами (особенно после изгнания иудеев из Испании в 1492 г.) ведущая роль в поддержании исторической памяти, сохранении (а иногда и формировании новых) обычаев, а также в исполнении этих обрядов переходила к женщинам. Когда в XVII в. общины испанских и португальских конверсо-изгнанников возвращаются к вере своих предков (то есть к иудаизму), происходит обратный процесс: их культура из преимущественно «женской» становится снова "мужской». Подобная гендерная «стратификация» присутствует и в других феноменах, на которые обращает свое внимание автор книги. Например, она указывает, что в критике культа Богоматери сосуществовали две тенденции: высокая, «мужская» еврейская полемика с этим культом, звучавшая в устах образованных конверсо, и народная, женское и не специфически еврейское «снижение» этого образа за счет обвинений Пресвятой Девы в том, в чем постоянно обвиняли самих женщин.

В заключение хотелось бы отметить, что книга Галины Зелениной, помимо несомненной научной глубины, обладает еще одним не менее важным достоинством. За выдержками из документов, авторскими рассуждениями и анализом встают судьбы живых людей с их проблемами, чувствами, страхами и надеждами. Галина Зеленина не пытается свести жизнь к схемам, идеализируя одних и демонизируя других, но воскрешает память об ушедших - таких, какими они были.

\author{
Zoya Metlitskaya (Russia) \\ Lomonosov Moscow State University, Historical Department \\ PhD, History \\ E-mail: betwuxalegednes@gmail.com \\ ORCID ID: 0000-0002-9031-2336
}

